\title{
Game Edukasi Belajar Mengaji Menggunakan Metode Linear Congruent Method (LCM) Berbasis Android
}

\author{
Lita Sari Muchlis ${ }^{1}$, Gerry Ronaldo Septianus ${ }^{2}$ \\ 1,2 Jurusan Manajemen Informatika, Fakultas Ekonomi dan Bisnis Islam, Institut Agama Islam Negeri \\ Batusangkar. Jalan Sudirman No. 137 Lima Kabupaten Tanah Datar Provinsi Sumatera Barat 27213 \\ e-mail: ${ }^{1}$ litasari.m@iainbatusangkar.ac.id, ${ }^{2}$ gerryronaldo23@gmail.com
}

Submitted Date: May 09 $09^{\text {th }}, 2020$
Revised Date: June $30^{\text {th }}, 2020$
Reviewed Date: May $11^{\text {th }}, 2020$

Accepted Date: June $30^{\text {th }}$, 2020

\begin{abstract}
Koran refers to the activity of reading the Qur'an. Koran is a skill that must be mastered by every Muslim and must be taught from an early age to children from the preschool age is the formation of the main character. But at this age still playing and when studying the Koran is still conventional with limited teaching methods. The method of learning for preschoolers requires interactive learning in the form of interactive audio visual education game. In the midst of a lot of research on educational learning games of the Koran, researchers focus on using the Linear Congruent Method (LCM). This linear congruent method model is used to randomize the quiz questions that will be presented. In developing each component of this educational learning learning game software using the Rapid Application Development (RAD) model. The results achieved from this study are in the form of teaching learning applications that are ready for use. This application can be used as the best solution to make it easier for preschool children to study Koran and data from distribution test results in graphical form showing system assessments with the percentage of satisfaction of this application using the Computer System Usability Questionnaire (CSUQ) to get a value with an average of $86.46 \%$ in. in the very decent category.
\end{abstract}

Keywords: Educational games; Koran; Linear congruent method (LCM); Rapid Application Development (RAD)

\begin{abstract}
Abstrak
Mengaji merujuk kepada aktivitas membaca Al-Qur'an. Mengaji adalah keterampilan yang harus dikuasai setiap muslim dan harus diajarkan dari dini kepada anak sejak usia prasekolah merupakan pembentukan watak yang utama. Namun pada usia ini masih bermain dan ketika dalam belajar mengaji masih konversional dengan metode pengajaran yang terbatas. Metode belajar kepada anak usia prasekolah dibutuhkan suatu pembelajaran yang interaktif berupa audio visual interaktif adalah game edukasi. Di tengah banyaknya penelitian tentang game edukasi belajar mengaji, peneliti fokus menggunakan metode Linear Congruent Method (LCM). Model linear congruent method ini digunakan untuk mengacak soal kuis yang akan disajikan. Dalam pengembangan setiap komponen perangkat lunak game edukasi belajar mengaji ini menggunakan model Rapid Application Development (RAD). Hasil yang dicapai dari penelitian ini berupa aplikasi belajar mengaji yang siap digunakan. Aplikasi ini dapat dijadikan solusi yang terbaik untuk mempermudah anak-anak usia prasekolah belajar mengaji dan data hasil pengujian distribusi dalam bentuk grafik menunjukkan penilain sistem dengan persentase kepuasan aplikasi ini mengunakan Computer System Usability Questionnaire (CSUQ) memperoleh nilai dengan rata-rata $86.46 \%$ yang masuk dalam kategori sangat layak.
\end{abstract}

Kata kunci: Game edukasi; Mengaji; Linear congruent method (LCM); Rapid Application Development (RAD) 


\section{Pendahuluan}

Mengaji merujuk kepada aktivitas membaca Al-Qur'an. Bagi setiap muslim mengaji merupakan sebuah keterampilan yang harus dikuasai karena Al-Qur'an merupakan pedoman dalam kehidupan sehari-hari. Belajar mengaji harus diajarkan kepada anak usia prasekolah karena masa itu pembentukan watak yang utama. Metode belajar yang sesuai untuk anak usia prasekolah adalah berupa audio visual agar anak cenderung lebih cepat tanggap. Salah satu media pembelajaran yang interaktif adalah game edukasi. Belajar menggunakan game edukasi mampu memberikan kondisi lebih rileks bagi anak ketika belajar, sehingga mereka tidak mengalami kelelahan ketika belajar (Citra, 2015; Darmawan, 2013). Game edukasi diyakini dapat meningkatkan motivasi belajar, dan hasil belajar siswa (Citra, 2015; Kordaki, 2011). Prestasi siswa yang belajar menggunakan game edukasi cenderung lebih tinggi dibandingkan dengan menggunakan aplikasi e-book (Citra, 2015; Hung, Huang, \& Hwang, 2014). Ini merupakan salah satu teknik pembelajaran unutk meningkatkan minat baca siswa sesuai genrenya (Daniarti, Taufiq, \& Sunaryo, 2020)

Pada saat ini sudah banyak pihak yang mengembangkan game edukasi sebagai sarana belajar mengaji untuk anak usia prasekolah. Terdapat banyak game edukasi belajar mengaji pada google play (android marketing yang menyediakan aplikasi-aplikasi untuk perangkat mobile dengan sistem operasi android). Namun belum ada yang memberikan soal-soal latihan secara acak. Pemberian latihan yang tidak dilakukan secara acak akan mempermudah anakanak saat memulai kembali game edukasi tersebut, sehingga menyebabkan anak-anak mengingat berdasarkan urutan soal latihan yang diberikan. Ketika ditanya bentuk tulisannya secara acak mereka kesulitan untuk menjawab. Selain itu pemberian soal latihan secara acak akan memberikan kesulitan tersendiri kepada anak-anak sehingga dapat meningkatkan kreatifis dan daya ingat anak.

Bilangan acak secara manual dapat dilakukan dengan cara undian. Namun, secara komputasi sulit dilakukan karena komputer adalah mesin deterministik (di mana tidak ada keacakan yang terlibat dalam pengembangan kondisi sistem di masa depan) sehingga bilangan yang muncul berupa probalistik yang sulit diprediksi. Cara lain untuk mendapatkan bilangan acak yang sering digunakan dalam program komputer adalah Linear Congruent Method (LCM) yaitu menggunakan pembangkit bilangan acak semu (generator pseudorandom) di mana bilangan acak diperoleh secara deterministik.

Pada penelitian ini bilaangan acak didapatkan dengan metode LCM yang diimpelementasikan untuk kasus pengacakan soal dengan aplikasi game pembelajaran anak usia dini Calistung (I. Dora, W. Rita, 2015). Penelitian lain dengan metode LCM dengan menyusun bank soal dengan mengacak dengan memperhatikan penggunaan konstatn $\mathrm{a}$, $\mathrm{c}$ dan $\mathrm{m}$ sehingga kombinasi konstanta yang tepat akan menghasilkan pengacakan soal yang benar (Arizqia \& Widodo, 2017). Pada Metode LCM dengan aplikasi Belajar Hiragama berhasil untuk pengacakan soal ujian dan pilihan jawaban ujian tebak suara dan menulis kata (Rahmad \& Pribadi, 2018). Pada saat ini belum ada game edukasi belajar mengaji yang menggunakan metode LCM.

Metode LCM memiliki kelebihan dalam hal kecepatan, kemudahan implementasi, dan ketersediaan kode portabel, parameter dan hasil tes (Mahmood, L. Rana, \& Khare, 2012; Supriyadi, Hamdani, \& Furqon, n.d.). Metode LCM memiliki waktu akses yang jauh lebih cepat dibandingkan dengan metode Fisher-Yates Shuffle. Untuk 500 jumlah data yang akan diacak, LCM hanya membutuhkan waktu 0,00033 second untuk mendapatkan bilangan acak. Sedangkan metode Fisher-Yates Shuffle membutuhkan waktu 0.0029 second untuk mendapatkan bilangan acak(Utama \& Asriningtias, 2017). Data sebagai dataset dalam database sangat diperlukan dalam penggunaan teknologi informasi dan komunikasi (Rusdi et al., 2019). LCM memiliki ciri-ciri terjadi pengulangan pada periode waktu tertentu.

Berdasarkan latar belakang masalah bagi anak usia prasekolah yang masih bermain dan ketika dalam belajar mengaji kurang focus dengan cara konvensional maka penelitian ini adalah bagaimana merancang game edukasi belajar mengaji menggunakan metode LCM berbasis android untuk anak usia prasekolah yang dapat membantu dan mempermudah anak-anak dalam belajar mengaji.

Adapun tujuan dari penelitian ini adalah untuk merancang sebuah game edukasi sebagai media belajar mengaji pada anak usia prasekolah yang mampu mempermudah anak-anak dalam mengingat huruf-huruf hijaiyah dengan baik.

\section{Metode Penelitian}

Untuk membangun perangkat lunak pada penelitian ini maka digunakan metode Rapid 
Application Development (RAD). RAD yang diilustrasikan pada Gambar 1 adalah model proses pengembangan perangkat lunak yang bersifat inkremental terutama untuk waktu pengerjaan yang pendek. Model RAD adalah adaptasi dari model air terjun versi kecepatan tinggi dengan menggunakan model air terjun untuk pengembangan setiap komponen perangkat lunak (Shalahuddin, 2016).

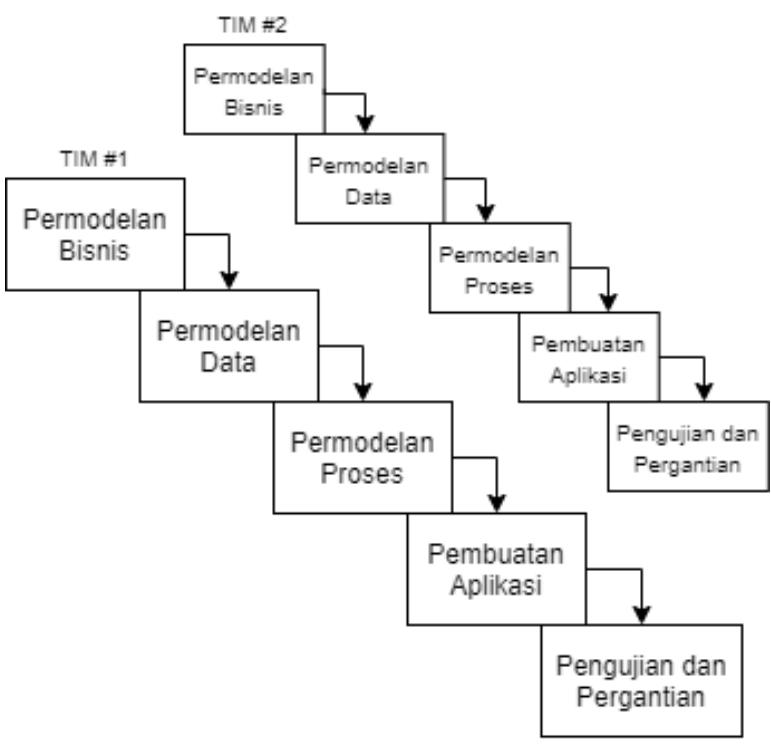

Gambar 1. Rapid Application Development

Pada tahapan pertama dilakukan permodelan bisnis dari sisi fungsi untuk mengetahui informasi apa yang terkait proses bisnis, informasi apa saja yang harus dibuat.

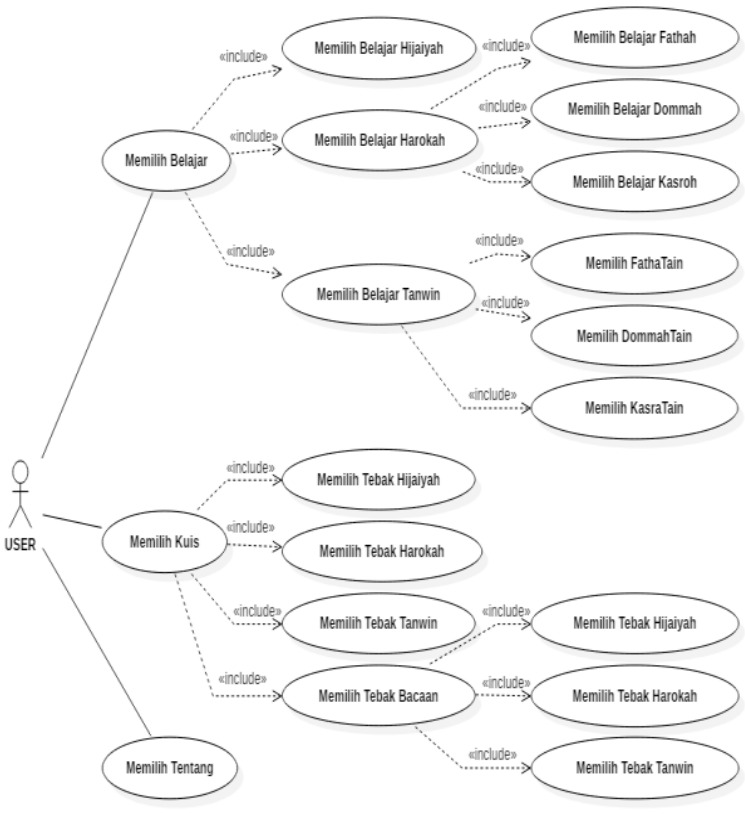

Gambar 2. Use Case Diagram
Bagaimana alur informasi itu, proses apa saja yang terkait informasi itu. Dimana penulis mengumpulkan dokumen serta melakukan pengamatan terhadap aplikasi belajar mengaji dengan android.

Memodelkan data apa saja yang dibutuhkan berdasarkan pemodelan bisnis dan mendefinisikan atribut-atributnya beserta relasinya dengan datadata lain. Pada tahap ini penulis menggunakan pemodelan Unifield madelling language (UML) dengan Use Case Diagram dan Activity Diagram.

Pada pemodelan proses dapat mengimplementasikan fungsi bisnis yang sudah didefinisikan terkait dengan pendefinisian data. Pada tahap ini penulis menggunakan pengembangan sistem dengan UML. UML adalah sebuah gambar yang memvisualisasikan, menspesifikasikan, membangun dari pemodelan dan desain program berorientasi objek (OOP) dan Metode yang digunakan dalam penelitian ini dengan LCM berbasis android.

Pada tahap pembuatan aplikasi mengimplementasikan pemodelan proses dan data yang sudah dirancang ke dalam bentuk program. Pada tahap ini penulis menggunakan bahasa pemograman JAVA dan dibantu aplikasi android studio sebagai editor kode pemograman. Penulis juga menggunakan aplikasi Corel Draw dan Photoshop sebagai alat bantu pembuatan desain interface.

Selanjutnya dilakukan pengujian aplikasi menggunakan dengan blackbox testing dan metode angket kepuasan Computer System Usability Questionnaire (CSUQ penggunaan aplikasi untuk mengetahui apakah aplikasi sudah bisa beroperasi dengan baik.

Untuk mengetahui informasi-informasi apa saja yang penulis butuhkan, maka penulis melakukan pengumpulan data dengan beberapa cara yaitu studi lapangan dan studi kepustakaan.

Penelitian lapangan adalah suatu teknik penelitian yang dilakukan secara langung pada objek penelitian. Penulis melakukan wawancara langsung dan observasi pada objek penelitian. Sehingga didapatkan informasi-informasi yang terkait sistem yang akan dibuat.

Studi literatur adalah pengumpulan data secara teoritis yang dilakukan dengan bantuan buku yang berhubungan dengan masalah yang diteliti, jurnal dan website. Penulis melakukan studi literatur pada penelitian-penelitian yang sepura namun dengan objek yang bebeda. Sehingga 
didapatlah informasi-informasi yang terkait sistem yang akan dibuat.

Berdasasrkan informasi-informasi yang sudah didapat pada pemodelan bisnis, maka penulis mengolah informasi-informasi tersebut sehingga didapatkan data-data apa saja yang dibutuhan untuk sistem yang akan dibuat.

\section{Hasil dan Pembahasan}

Untuk mempermudah pemodelan proses, maka penulis menggunakan pemodelan Unifield Modelling Language (UML). UML merupakan bahasa untuk visualisasi, spesifikasi, kontruksi, serta dokumentasi (Adi, 2005). Untuk membuat suatu model, UML mendefinisikan diagramdiagram grafis yaitu usecase diagram, sequence diagram, class diagram, dan activity diagram (Aji Supriyanto, 2005). Namun pada penelitian ini penulis hanya menggunakan use case diagram dan activity diagram.

Use Case Diagram pada game edukasi belajar mengaji ini menggambarkan interaksi antara user dengan game edukasi itu sendiri dan ditunjukkan pada Gambar 2.

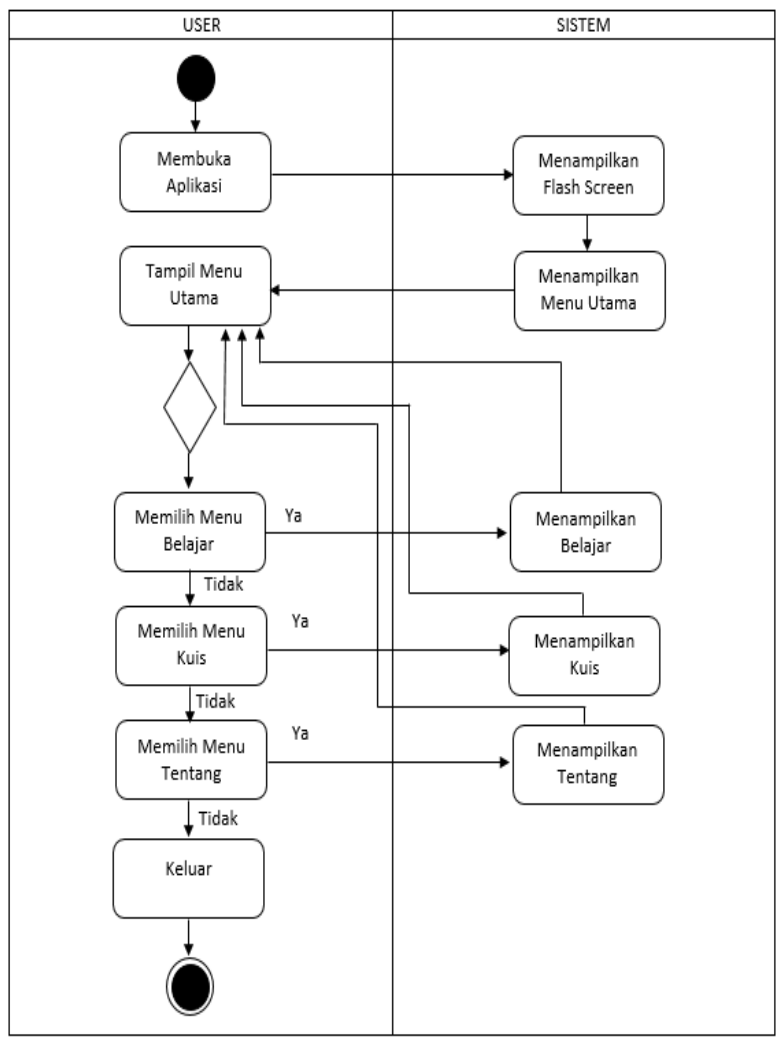

Gambar 3. Activity Diagram

Activity diagram pada game edukasi belajar mengaji yang dibuat menggambarkan aliran kerja dari game edukasi. Activity diagram dari game edukasi untuk belajar mengaji digambarkan pada Gambar 3. Diagram tersebut menggambarkan bahwa user dapat memilih menu-menu yang terdapat pada game tersebut, yaitu menu belajar dan kuis.

\subsection{Pembuatan Aplikasi}

Aplikasi game edukasi belajar mengaji ini dikembangkan sesuai dengan metode RAD dan telah dihasilkan sebuah game yang sesuai dengan tujuan dari

penelitian ini. Pada bagian ini akan dijelaskan desain antar muka pada game yang akan dirancang pada menu utama dari game edukasi yang dirancang.

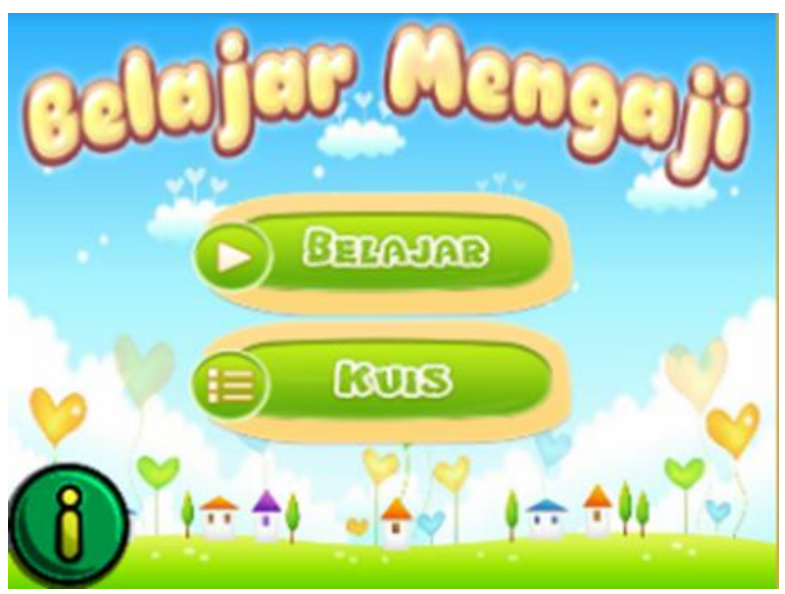

Gambar 4. Desain Halaman Awal

Pada Gambar 4 dapat dilihat bahwa halaman awal terdiri dari judul game serta tombol-tombol yaitu tombol belajar, kuis dan tentang.

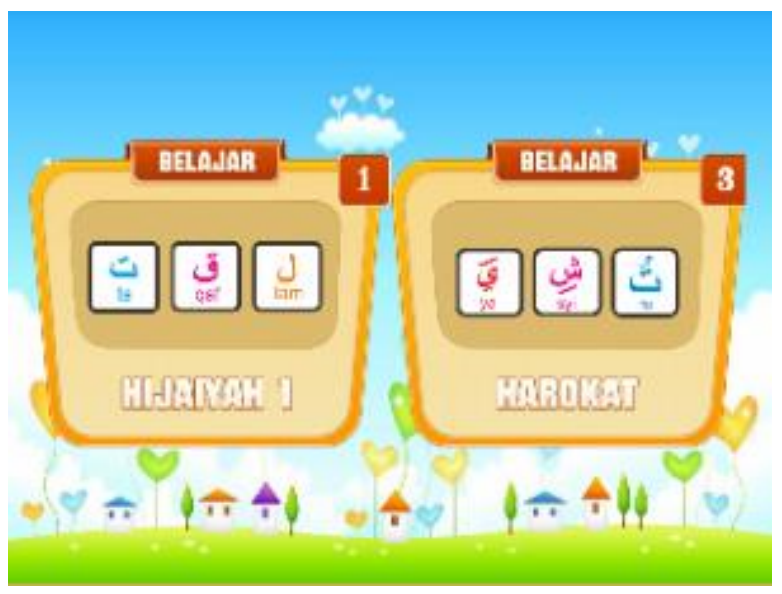

Gambar 5. Desain Halaman Belajar 
Pada Gambar 5 dapat dilihat bahwa pada halaman belajar terdapat pop up (muncul) huruf hijaiyah dan beberapa tombol yaitu tombol kembali, huruf-huruf hijaiyah pada bagian bawah.

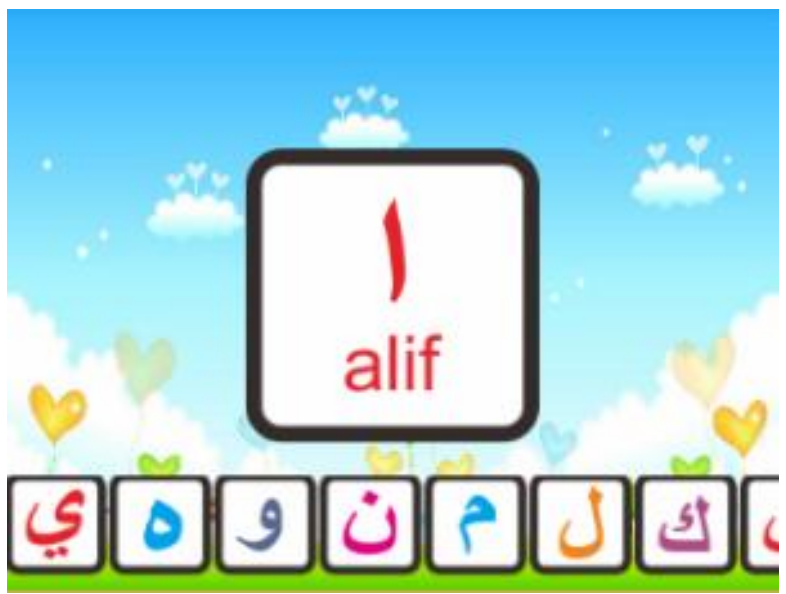

Gambar 6. Tampilan Belajar

Pada Gambar 6 dapat dilihat bahwa pada halaman belajar hijaiyah terdapat pop up (muncul) huruf hijaiyah dan beberapa tombol yaitu tombol kembali, huruf-huruf hijaiyah pada bagian bawah.

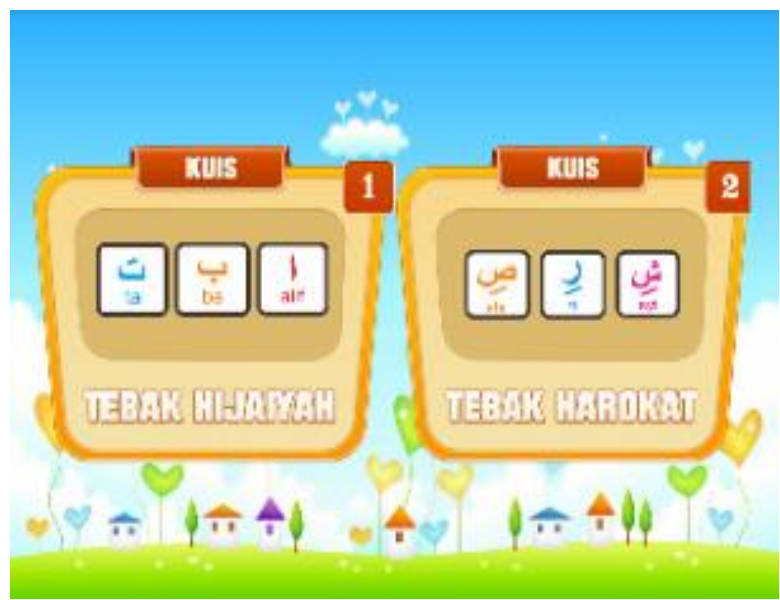

Gambar 7. Desain Menu Kuis

Pada Gambar 7 terdapat 5 tombol yaitu tombol tebak hijaiyah, tombol tebak harokat, tombol tebak tanwin, tombol tebak bacaan, tombol tebak kembali.

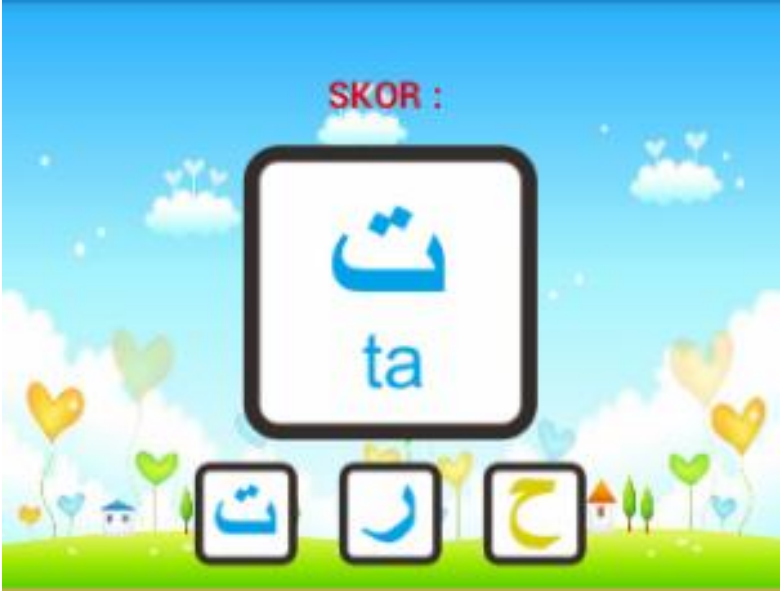

Gambar 8. Desain Halaman Kuis

Pada Gambar 8 bisa kita lihat terdapat tampilan pop up tebak hijaiyah dan beberapa tombol yaitu tombol kembali dan huruf- huruh hijaiyah.

\subsection{Pembahasan}

Pada game edukasi belajar mengaji ini terdapat 28 huruf hijaiyah dengan harokat dan tanwin. Huruf Hijaiyah yang digunakan: alif ( 1 ), ba (ب), ta ( ت), tsa ( $)$ ), jim ( ج), ha ( ح), Kho ( $\dot{\tau})$, dal ( د), dzal ( $)$, ro ( J), za ( j), sin ( w), syin ( ش), shod ( ص ), dhod (ض), tho ( ط ), dho ( ظ ),

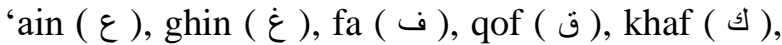

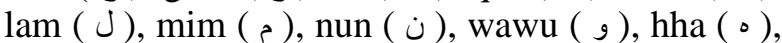
yak (ي). Harokat yang digunakan adalah: fathah, kasroh, dhomah. Tanwin yang digunakan adalah: fathah tain, kasroh tain, dan dhomah. Game edukasi ini memiliki 4 menu utama yaitu belajar, kuis, about, keluar.

Pada menu belajar terdapat tiga macam materi yaitu menu hijaiyah, menu harokat, dan menu tanwin. Pada menu hijaiyah, materi-materi yang ditampilkan adalah huruf hijaiyah tanpa tanda baca. Pada menu harokat, materi yang ditampilkan adalah huruf hijaiyah menggunakan harokat. Pada menu tanwin materi yang ditampilkan adalah huruf hijaiyah dengan tanwin.

Pada menu kuis terdapat empat jenis kuis yaitu tebak hijaiyah, tebak harokat, tebak tanwin, dan tebak bacaan. Pada tebak hijaiyah kuis yang diberikan adalah huruf-huruf hijaiyah. Pada tebak hijaiyah terdapat sistem skor dimana jika user menebak benar akan mendapatkan poin 10, namun jika user salah dalam menebak huruf hijaiyah maka poin user akan dikurangi 5 poin. Tujuan dari tebak hijaiyah adalah menebak semua huruf hijaiyah yang ditampilkan pada kuis tebak hijaiyah dan 
mendapatkan skor setinggi-tingginya. Sistem kuis pada tebak harokat hampir sama dengan tebak hijaiyah di mana user akan diberikan kuis tentang huruf hijaiyah namun huruf hijaiyah tersebut sudah menggunakan harokat. Sistem poin pada kuis tebak harokat adalah jika user menebak benar soal kuis yang diberikan maka poin user akan ditambah 10, namun jika user salah menebak maka poin user akan dikurangi 5. Tujuan dari tebak harokat ini adalah menebak sebanyak-banyaknya soal kuis yang diberikan dan mendapatkan skor setinggitingginya. Pada tebak tanwin, soal kuis yang diberikan adalah huruf hijaiyah dengan tanwin. Untuk sistem kuisnya jika user menjawab benar maka poin akan ditambah 10 , namun jika salah akan dikurangi 5. Tujuan dari kuis tebak tanwin adalah untuk mendapatkan poin setinggi-tingginya dengan cara menjawab soal-soal kuis dengan benar sebanyak-banyaknya. Pada tebak bacaan materi kuis yang diberikan tidak lagi dalam bentuk huruf hijaiyah, namun dalam bentuk bacaan. User akan diminta untuk menebak bacaan dari soal kuis yang diberikan. Untuk sistem poinnya jika player menjawab benar maka poin akan bertambah 10 namun jika salah poin akan dikurangi 5 .

Berdasarkan pemodelan data dan pemodelan proses, penulis melakukan pembuatan game edukasi dalam bentuk program dan mengimplementasikan logika Metode LCM pada game edukasi yang akan dibuat.

Metode LCM memanfaatkan model linier untuk membangkitkan bilangan acak yang didefinisikan sebagai berikut:

$$
X n+1=(a \cdot X n+c) \bmod m
$$

Dimana:

$$
\begin{array}{ll}
\mathrm{Xn} & =\text { bilangan acak ke } \mathrm{n}, \\
\mathrm{A} & =\text { faktor pengali, } 0<\mathrm{a}<\mathrm{m} \\
\mathrm{c} & =\text { faktor penambah, } 0 \leq \mathrm{c}<\mathrm{m} \\
\mathrm{m} & =\text { modulus, } 0<\mathrm{m}
\end{array}
$$

(a, c, m adalah konstan)

Untuk mengimplementasikan fungsi LCM, pertama kita harus menentukan konstantannya terlebih dahulu. Penulis menggunakan konstanta sebagai berikut:

$$
\begin{aligned}
\mathrm{a}= & 1, \mathrm{c}=7, \mathrm{~m}=30 \mathrm{dan} \mathrm{x}(0)=1 \\
& \mathrm{X}(1)=1 \\
& \mathrm{X}(1)=(1 * 1+7) \bmod 30=8 \\
& \mathrm{X}(2)=(1 * 8+7) \bmod 30=15 \\
& \mathrm{X}(3)=(1 * 15+7) \bmod 30=22 \\
& X(4)=(1 * 22+7) \bmod 30=29
\end{aligned}
$$

$$
\begin{aligned}
& X(5)=(1 * 29+7) \bmod 30=6 \\
& X(6)=(1 * 6+7) \bmod 30=13 \\
& X(7)=(1 * 13+7) \bmod 30=20 \\
& X(8)=(1 * 20+7) \bmod 30=27 \\
& X(9)=(1 * 27+7) \bmod 30=4 \\
& X(10)=(1 * 4+7) \bmod 30=11 \\
& X(11)=(1 * 11+7) \bmod 30=18 \\
& X(12)=(1 * 18+7) \bmod 30=25 \\
& X(13)=(1 * 25+7) \bmod 30=2 \\
& X(14)=(1 * 2+7) \bmod 30=9 \\
& X(15)=(1 * 9+7) \bmod 30=16 \\
& X(16)=(1 * 16+7) \bmod 30=23 \\
& X(17)=(1 * 23+7) \bmod 30=0 \\
& X 1(18)=(1 * 0+7) \bmod 30=7 \\
& X(19)=(1 * 7+7) \bmod 30=14 \\
& X(20)=(1 * 14+7) \bmod 30=21 \\
& X(21)=(1 * 21+7) \bmod 30=28 \\
& X(22)=(1 * 28+7) \bmod 30=5 \\
& X(23)=(1 * 5+7) \bmod 30=12 \\
& X(24)=(1 * 12+7) \bmod 30=19 \\
& X(25)=(1 * 19+7) \bmod 30=26 \\
& X(26)=(1 * 26+7) \bmod 30=3 \\
& X(17)=(1 * 3+7) \bmod 30=10 \\
& X(28)=(1 * 10+7) \bmod 30=17 \\
& X(29)=(1 * 17+7) \bmod 30=24
\end{aligned}
$$

Dari penyelesaian diatas didapatkan hasil: 1 , $8,15,22,29,6,13,20,27,4,11,18,25,2,9,6,23$, $0,7,14,21,28,5,12,19,26,3,10,17,24$.

\subsection{Pengujian Dan Pergantian}

Pada penelitian ini penulis melakukan uji blackbox dan system testing untuk mengetahui tingkat keberhasilan dari game edukasi ini. Pengujian bertujuan untuk menguji fungsional perangkat lunak. Hasilnya bisa dilihat pada Tabel 1.

Tabel 1. Uji Black Box

\begin{tabular}{|l|l|l|}
\hline Aksi Aktor & \multicolumn{1}{|c|}{ Reaksi Sistem } & Hasil \\
\hline Memulai aplikasi & $\begin{array}{l}\text { Menampilkan flash } \\
\text { screen } \\
\text { Menampilkan } \\
\text { halaman utama }\end{array}$ & Sukses \\
\hline $\begin{array}{l}\text { Memilih menu } \\
\text { belajar pada } \\
\text { halaman utama }\end{array}$ & $\begin{array}{l}\text { Menampilkan sub } \\
\text { menu belajar }\end{array}$ & Sukses \\
\hline $\begin{array}{l}\text { Memilih salah satu } \\
\text { sub menu belajar }\end{array}$ & $\begin{array}{l}\text { Menampilkan materi } \\
\text { belajar yang sesuai } \\
\text { dengan judul sub } \\
\text { menu }\end{array}$ & Sukses \\
\hline $\begin{array}{l}\text { Memilih menu kuis } \\
\text { pada halaman utama }\end{array}$ & $\begin{array}{l}\text { Menampilkan sub } \\
\text { menu kuis }\end{array}$ & sukses \\
\hline
\end{tabular}




\begin{tabular}{|l|l|l|}
\hline $\begin{array}{l}\text { Memilih salah satu } \\
\text { sub menu belajar }\end{array}$ & $\begin{array}{l}\text { Menampilkan soal } \\
\text { kuis yang sesuai } \\
\text { dengan judul sub } \\
\text { menu }\end{array}$ & Sukses \\
\hline $\begin{array}{l}\text { Memilih halaman } \\
\text { tentang }\end{array}$ & $\begin{array}{l}\text { Menampilkan data } \\
\text { tentang game }\end{array}$ & Sukses \\
\hline $\begin{array}{l}\text { Hasil dari skor } \\
\text { ketika kuis sesuai } \\
\text { dengan hasil dari } \\
\text { jawaban }\end{array}$ & $\begin{array}{l}\text { Menampilkan skor } \\
\text { dari menjawab kuis } \\
\text { yang dilakukan }\end{array}$ & Sukses \\
\hline Keluar dari aplikasi & Menutup aplikasi & sukses \\
\hline
\end{tabular}
berikut:

Sedangkan persentase hasilnya yaitu sebagai

$$
\begin{aligned}
\text { Berhasil } & =\frac{8}{7} \times 100 \%=100 \% \\
\text { Gagal } & =\frac{0}{8} \times 100 \%=0 \%
\end{aligned}
$$

Dari hasil uji black box yang sudah dilakukan didapatkan hasil yang sangat baik.

Tahapan system testing bertujuan untuk menguji kecocokan sistem yang dibuat dengan platform yang digunakan. Pengujian dilakukan menggunakan 3 perangkat smartphone yang berbeda. Hasilnya bisa dilihat pada Tabel 2 .

Tabel 2. System Testing

\begin{tabular}{|l|ll|l|}
\hline Merk & \multicolumn{2}{|l|}{ Spesifikasi } & Status \\
\hline Samsung & Android versi & sukses \\
Galaxy V Duos & 4.4 .2 & & \\
\hline Asus zenfone 2 & $\begin{array}{l}\text { Android } \\
5.0\end{array}$ & versi & sukses \\
\hline Oppo Neo 5 & $\begin{array}{l}\text { Android versi } \\
5.1\end{array}$ & sukses \\
\hline
\end{tabular}
berikut:

Persentase hasil system testing yaitu sebagai

$$
\begin{aligned}
\text { Berhasil } & =\frac{3}{3} X 100 \%=100 \% \\
\text { Gagal } & =\frac{0}{3} X 100 \%=0 \%
\end{aligned}
$$

Pengujian dilakukan pada smartphone versi android Kitkat dan Lollipop. Berdasarkan Tabel 2 bisa kita ketahui game edukasi ini dapat di-install dan berjalan dengan baik dan lancar pada android versi lama sekalipun.

Untuk mengukur manfaat aplikasi ini, maka dilakukan pengujian penggunaan aplikasi dengan metode angket Computer System Usability
Questionnaire (CSUQ) (Taylor \& Lewis, 2009). Angket diberikan kepada guru Pendidikan Anak Usia Dini dan Taman Kanak-kanak sebanyak 19 orang.

Lewis mengukur angket tanpa ada perubahan jumlah pertanyaan, data interval dan skor penilaian 1 hingga 7 dengan menggunakan rumus persentase sebagai berikut:

Hasil $=\frac{\text { Total Skor yang diperoleh } h}{\text { skor maksimum }} \times 100 \%$

Kategori kelayakan aplikasi dengan angket berdasarkan kriteria (Suharsimi, Arikunto \& Cepi,

\begin{tabular}{|c|c|c|c|c|}
\hline \multicolumn{2}{|c|}{ Score Name } & Item & Persentase & Kategori \\
\hline \multirow{19}{*}{ 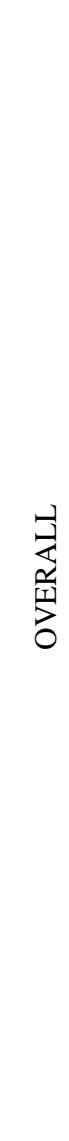 } & \multirow{8}{*}{ 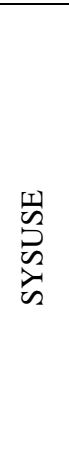 } & P1 & 90.23 & Sangat layak \\
\hline & & $\mathrm{P} 2$ & 90.23 & Sangat layak \\
\hline & & P3 & 85.71 & Sangat layak \\
\hline & & P4 & 84.96 & Sangat layak \\
\hline & & P5 & 93.98 & Sangat layak \\
\hline & & P6 & 88.72 & Sangat layak \\
\hline & & P7 & 78.20 & Layak \\
\hline & & P8 & 69.17 & Layak \\
\hline & \multirow{7}{*}{$\begin{array}{l}\text { 它 } \\
\text { 己 } \\
\text { O } \\
\text { 至 }\end{array}$} & P9 & 90.98 & Sangat layak \\
\hline & & P10 & 74.44 & Layak \\
\hline & & P11 & 92.48 & Sangat layak \\
\hline & & P12 & 89.47 & Sangat layak \\
\hline & & P13 & 84.96 & Sangat layak \\
\hline & & P14 & 79.70 & Layak \\
\hline & & P15 & 96.99 & Sangat layak \\
\hline & \multirow{4}{*}{ 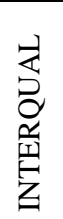 } & P16 & 85.71 & Sangat layak \\
\hline & & P17 & 87.22 & Sangat layak \\
\hline & & P18 & 87.97 & Sangat layak \\
\hline & & P19 & 91.73 & Sangat layak \\
\hline
\end{tabular}
2009). Berikut hasil dari pengujian kriteria data usability pada Tabel 3.

Tabel 3. data hasil pengujian usability

Distribusi hasil pengujian usability berdasarkan Score name dapat dilihat pada Gambar 9. 


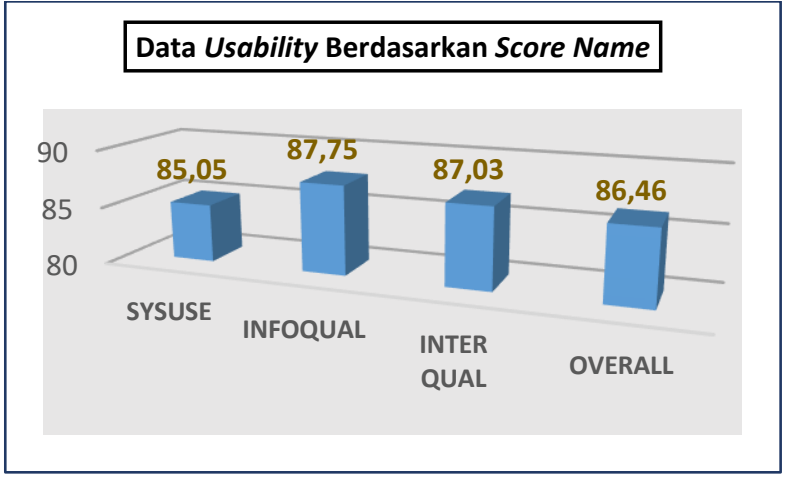

Gambar 9. Data Usability Berdasarkan Score Name

Data hasil pengujian dan distribusi dalam bentuk grafik menunjukkan penilaian sistem dengan persentase sysuse, infogual, interqual dan overall. Berdasarkan persentase dari aspek sysuse memperoleh nilai rata-rata $85.05 \%$ dan masuk kedalam kategori sangat layak. Aspek infogual memperoleh nilai rata-rata $87.75 \%$. Sedangkan pada aspek interqual memperoleh nilai rata-rata $87.03 \%$. Adapun total persentase dari keseluruhan aspek overall memperoleh nilai dengan rata-rata $86.46 \%$ yang masuk dalam kategori sangat layak. Hasil pengujian usability angket dengan metode CSUQ dapat disimpulkan bahwa game edukasi belajar mengaji menggunakan metode Linear Congruent Method (LCM) berbasis android dikategorikan sangat layak untuk digunakan

\section{Kesimpulan}

Perancangan game edukasi belajar mengaji menggunakan metode linear congruent method (LCM) berbasis android ini menggunakan Rapid Application Development sebagai alat bantu pengembangan sistemnya. Game edukasi belajar mengaji ini telah diuji menggunakan uji black box dengan hasil yang sangat baik dan hasil pengujian distribusi dalam bentuk grafik menunjukkan penilain sistem dengan presentase kepuasan aplikasi ini mengunakan Computer System Usability Questionnaire (CSUQ) memperoleh nilai dengan rata-rata $86.46 \%$ yang masuk dalam kategori sangat layak. Selain itu game edukasi belajar mengaji ini bisa berjalan dengan baik diberbagai versi android minimal android versi 4.0.0

Game edukasi ini memiliki beberapa kelebihan seperti soal kuis yang disajikan diacak, mudah digunakan, desain interface dan suara dan yang menarik. Selain itu, aplikasi ini juga memiliki beberapa kekurangan diantaranya kuis pada game edukasi belajar mengaji ini termasuk simpel, game edukasi belajar mengaji ini hanya pada pengenalan huruf hijaiyah, haraqah, dan tanwin saja, belum adanya database sehingga tidak bisa melihat data nilai kuis sebelumnya.

Game edukasi ini dapat dikembangkan pada game yang membahas tentang iqra dan alquran menggunakan tajwin dengan konsep score board dan multiplayer game.

\section{Referensi}

Adi, N. (2005). Analisa Dan Perancangan Sistem Informasi Dengan Metodologi Berorientasi Objek. Bandung: Informatika Bandung.

Aji, S. (2005). Pengantar Teknologi Informasi. Jakarta: Salemba Infotek.

Arizqia, M. G., \& Widodo, A. A. (2017). Rancang Bangun Aplikasi Dengan Linear Congruent Method (LCM) Sebagai Pengacakan Soal. JOINTECS (Journal of Information Technology and Computer Science), 2(1), 1-6. https://doi.org/10.31328/jointecs.v2i1.412

Citra, P. (2015). Game Edukasi Android Untuk Belajar Membaca Tanpa Mengeja Desain , Pembuatan dan Evaluasi Sampel.

Daniarti, Y., Taufiq, R., \& Sunaryo, B. (2020). The Implementation of Teaching Reading Through Genre Based Approach for University Students. Journal of Physics: Conference Series, 1477(4). https://doi.org/10.1088/17426596/1477/4/042064

Darmawan, D. (2013). teknologi-pembelajaran. Bandung: PT Remaja Rosdakarya Offset.

Hung, C.-M., Huang, I., \& Hwang, G.-J. (2014). Effects of digital game-based learning on students' selfefficacy, motivation, anxiety, and achievements in learning mathematics. Journal of Computers in Education, 1(2-3), 151-166. https://doi.org/10.1007/s40692-014-0008-8

I. Dora, W. Rita, P. S. (2015). Perancangan Aplikasi Game Edukasi Pembelajaran Anak Usia Dini Menggunakan Linear Congruent Method ( Lcm ) Berbasis Android. Jurnal Informatika Global, 6(1), 7-14. https://doi.org/10.36982/jig.v6i1.4

Kordaki, M. (2011). A computer card game for the learning of basic aspects of the binary system in primary education: Design and pilot evaluation. Education and Information Technologies, Vol. 16, pp. 395-421. https://doi.org/10.1007/s10639-0109136-6

Mahmood, Z., L. Rana, J., \& Khare, A. (2012). Symmetric Key Cryptography using Dynamic Key and Linear Congruential Generator (LCG). International Journal of Computer Applications, 50(19), 7-11. https://doi.org/10.5120/7908-0973

Rahmad, A. N., \& Pribadi, F. S. (2018). Edu Komputika Journal. Edu Komputika Journal, 5(1), 33-43.

Rusdi, J. F., Salam, S., Abu, N. A., Sunaryo, B., Taufiq, 
R., Muchlis, L. S., ... Vitianingsih, A. V. (2019). Dataset smartphone usage of international tourist behavior. Data in Brief, 27. https://doi.org/10.1016/j.dib.2019.104610

Shalahuddin, R. A. s M. (2016). Jual Rekayasa Perangkat Lunak by Rosa A. Bandung: Informatika Bandung.

Suharsimi, Arikunto \& Cepi, S. A. J. (2009). Suharsimi oke. Jakarta: Bumi Aksara.

Supriyadi, S., Hamdani, D., \& Furqon, Y. M. (n.d.). Rancang Bangun Alfabet Memory Game Menggunakan Linear Congruent Method ( Lcm ). 45513(36).

Taylor, P., \& Lewis, J. R. (2009). IBM computer usability satisfaction questionnaires :
Psychometric evaluation and instructions for use IBM Computer Usability Satisfaction Questionnaires: Psychometric Evaluation and Instructions for Use. International Journal of Human-Computer Interaction, (December 2012), 37-41.

Utama, D. S., \& Asriningtias, Y. (2017). Perbandingan Waktu Akses Algoritma Fisher-Yates Shuffel Dan Linear Congruent Method Pada Soal Try-Out Berbasis Web. JISKA (Jurnal Informatika Sunan Kalijaga), 2(2), 93. https://doi.org/10.14421/jiska.2017.22-04 